\title{
Critical Success Factors in Business Operation and Its Impact on Productivity Growth
}

\author{
Rahimi Abidin ${ }^{1, *}$ Nor Hasni Osman ${ }^{1,}$ Rushanim Hashim ${ }^{1}$ \\ ${ }^{I}$ School of Technology Management \& Logistics, Universiti Utara Malaysia, Sintok, Kedah, \\ "Corresponding author. Email:a.rahimi@uum.edu.my
}

\begin{abstract}
Service sector in Malaysia continues to be the top source of employment. In the private sector, most jobs are created in sub-sectors such as trade, tourism, finance, insurance and business services. These industries operate in a competitive environment where customers are increasingly able to make choices. In a volatile business environment with rapid changes in regional and global markets, industry players need to emphasis on key success factors that enable organizations to track and measure progress toward achieving their strategic goals and meeting their mission. This study highlighted critical success factors in business operation among industry player in the services sector, which may contribute to the productivity growth. A survey was conducted with a total of 542 industry players who involve in completing the questionnaire. Descriptive and correlation analysis were used to analyze the critical factors that need to be considered in operating their businesses. Based on the result, it can be concluded that in sustaining and achieving a better performance, the companies in service sectors focus on the realization in operation management, followed by market positioning, marketing and distribution network, business diversification, cost structure, project management and raw material procurement. The finding also shows that all these factors are significantly contributing to the productivity growth in the service sector.
\end{abstract}

Keywords: Service sector, business management, strategic, productivity, sustainable

\section{INTRODUCTION}

The services sector in Malaysia continues to be the top source of employment, accounting for 52.2 percent of total employment by 2025 [1]. In the private sector, the majority of jobs to be created are in sub-sectors such as trade, tourism, finance, insurance and business services. Operating in a competitive environment where customers are increasingly able to make choices industry players need to emphasis on key success factors in their business operation that enable the organizations to track and measure progress toward achieving their strategic goals and meeting their mission. According to $\mathrm{Yu}$ and Ramanathan [2], a firm's survival depends on its ability to create, access, and utilize new resources, build on its capability platform, and make the capabilities more inimitable to achieve competitive advantage. Business operation varies across each industry. The operations of a business are structured based on the requirements of the specific industries. To achieve success in a business, the industry players have to get off by heart the operations of the industry and the critical success factor of the business operation. This study attempts to identify the critical success factor of service industries in one of the states in Malaysia. Besides, it also seeks to find the impact of these factors on the productivity of the state.

Identifying critical success factors enables an organization to track and measure progress toward achieving its strategic goals and fulfil its mission. Critical success factors are a common reference for individuals in the organization so they all know what matters most and to ensure that tasks and projects are aligned across departments. There are many issues that may affect the achievement of a business operation. Based on the discussion in the Resource Based View (RBV) theory, to develop and maintain competitive advantages of a business, it requires valuable, rare, inimitable and nonsubstitutable resources [3]. However, in a global competitive environment, ways to achieve competitive advantage are changing very fast. Therefore, besides having the ability to utilize resources and capabilities in coupled and innovate ways, the industrial players must 
have timely strategies [4]. In this study, seven factors have been identified and examined. The factors considered in this study are market position, business diversification, raw material procurement, operation management, project management, marketing and distribution network and cost structure.

\subsection{Market Positioning}

Companies use positioning strategies to differentiate their services from competitors and to design communications that lead the way to their desired position with customers and prospects [5]. Market positioning or the ability to influence consumer perception regarding a brand or product comparison to competitors is an advantage to a company. It benefits the company in establishing the image or identity of a brand or product. The company should achieve an understanding of what it is, how it is different from competitors, the conditions of the marketplace, opportunities in the marketplace, and how it can position itself. Previous studies [6][7] shows that positioning activities have positive influence on the company performance in terms of profitability and efficiency [8].

\subsection{Business Diversification}

Diversification is an act of an existing company expanding into a new business opportunity [9]. This corporate strategy enables the company to enter into a new market segment. The decision to diversify can prove to be a challenging decision for the company as it can lead to extraordinary rewards with risks. Among the reasons why firms decide for diversification are to ensure maximum utilization of the existing resources and capabilities, to escape from unattractive industrial environments and for growth in business operations. Among the advantages of diversification is as the economy changes, the spending patterns of the people change. Diversification into a number of industries or product line can help create a balance for the entity during these ups and downs. There will always be unpleasant surprises within a single investment. Being diversified can help in balancing such surprises. Diversification helps to maximize the use of potentially underutilized resources.

Diversification is a corporate strategy to enter into a new products or product lines, new services or new markets, involving substantially different skills, technology and knowledge. There are many, and somehow contradictory, theoretical arguments in the literature to explain the relationship between the diversification strategy and firm performance, suggesting that diversification may have both value enhancing and value reducing effects [10].

\subsection{Raw Material Procurement}

Because businesses typically spend such a large portion of their revenue on these goods and services, most develop strategic procedures to ensure that their purchases are providing value in addition to resources. Procurement is a systematic process within the supply chain in which business leaders approach spending analytically. It is often considered a key component of a company's overall corporate strategy as it aligns the company's overall objectives with their short- and longterm goals. Because it touches upon so many aspects of the corporate strategy, the procurement process typically requires precise calibration between multiple departments.

Successful procurement management can add tangible value to an organization's bottom line and is best handled by a team of qualified individuals. With expertise in key areas like cost savings, risk management, compliance, centralized purchasing, and contract management, the best procurement teams streamline all of a company spend mechanisms into a singular system.

\subsection{Operation Management}

Operations management for services has the functional responsibility for producing the services of an organization and providing them directly to its customers [10][19]. The services sector treats services as imperceptible products. Service is as a customer experience and service as a package of facilitating goods and services. According to Mary et al [11], encompasses the management of systems or processes that create goods or provide services, it identifies all the activities necessary to plan, develop and improve the business processes involved in the manufacturing of a product or in the provision of a service [12]. These decisions take into account the process, people, information and the system that produces and delivers the service. It differs from operations management in general, since the processes of service organizations differ from those of manufacturing organizations.

Successful procurement management can add tangible value to an organization's bottom line and is best handled by a team of qualified individuals. With expertise in key areas like cost savings, risk management, compliance, centralized purchasing, and contract management, the best procurement teams streamline all of a company spend mechanisms into a singular system.

\subsection{Project Management}

Projects are setting out to achieve a defined goal that will change or enhance the basic operation of the business. Unlike processes, which make it possible to consistently replicate the same tasks, projects set out to create new products, new strategies, and new ways of 
doing business. The important person in project management is the project managers. A project manager is responsible for organizing ideas and creating a plan to accomplish the goal by designing and manage the project budget, gather a project team, and determine what tasks are needed to move from start to finish [10]. The project manager is responsible for mitigating those risks to ensure the project's success.

Once the project is complete, the results could become a business process. For example, a project that has successfully designed and implements a new customer service model will lead to new customer service processes that are repeated by staff members in each customer service interaction.

\subsection{Marketing and Distribution Network}

Businesses engage in marketing and advertising to promote their product, provide information, and make product recommendations. The promotion allows businesses to improve sales by reaching more segmented end-users [13].

Distribution network design choices contribute significantly to supply chain performance both in terms of costs and consumer service level. An effective distribution network design can lead to significant decrease in logistics costs while increasing, or at least maintaining the service level [14].

Distribution network configuration is also closely related to marketing, channel theories, where its role is described as closing the gap between manufactures and consumers regarding time, geography, quantity and variety of products [15] [16]. Thus, it can be considered as one of the key drivers for companies' performance [17].

\subsection{Cost Structure}

A review of European surveys relating to cost structures of firms shows that direct material costs tend to be higher than indirect costs. They conclude that if indirect costs make up a relatively small proportion of total costs in some industries it may not be worthwhile investing in sophisticated accounting methods to allocate indirect costs [17]. In such cases direct costing may be appropriate or, if indirect costs are assigned to cost objects, traditional costing systems may not result in reporting seriously distorted costs".

\section{METHODOLOGY}

This study attempts to identify the critical factors in business operation in service industries that may have an influence on the productivity of the businesses. A crosssectional research design has been used as it capable of using data from a large number of subjects and not geographically bound. The data were collected at one point in time through a survey on the industry player in service sectors to find the relationship between variables.

Within this approach we can distinguish two main categories of surveys those are explorative and explicative [8]. The first category is explorative or descriptive where the survey was conducted to study the current state of a phenomenon, in a chosen population. While, for the second category is explicative which is also known as relational. The purpose is to test a certain hypothesis and the relationships among the variables which are the object of the investigation.

The population of the study is the industrial players of service sector, which operating in Pahang. Pahang is one of the largest state in peninsular Malaysia with various tourist locations catalyse a variety of industries in the services sector. There are eleven districts of Pahang state, therefore, stratified sampling was used in the data collection to ensure the respondents from the eleven districts involved and represented in the sample. Data of 542 industry players from the eleven districts of Pahang was analysed using descriptive and correlation analyses. The respondents were asked to indicate the critical success factor of their business and rate the level of satisfaction on the selected factors based on the perspective of the state industrial development and the extent it contributes to the productivity based on 5-point scale from 1 (very low) to 5 (very high).

\section{RESULTS AND DISCUSSION}

The finding shows that the highest number of respondents designated operations management as a critical success factor, followed by marketing frameworks, market positioning, and business distribution and diversification (Table 1).

Table 1. Critical Success Factors

\begin{tabular}{|l|c|c|}
\hline $\begin{array}{c}\text { Please indicate the critical } \\
\text { success factor of your business }\end{array}$ & Frequency & Percent \\
\hline Market position & 312 & 57.6 \\
\hline Business diversification & 300 & 55.4 \\
\hline Raw material procurement & 174 & 32.1 \\
\hline Operations management & 320 & 59.0 \\
\hline Project management & 179 & 33.0 \\
\hline Marketing \& distribution network & 303 & 55.9 \\
\hline Cost structure & 238 & 43.9 \\
\hline
\end{tabular}

Table 2 shows the satisfaction level of the respondents from industrial player of service sector on the selected critical success factors from the perspective of the state industrial development. It is found that the satisfaction level in the moderate level with range of the mean score between 3.206 to 3.427 . 
Table 2. Mean Score of Satisfaction on Critical Success Factors

\begin{tabular}{|l|l|}
\hline \multicolumn{1}{|c|}{ Critical Success Factor } & Mean \\
\hline Market position & 3.420 \\
\hline Business diversification & 3.433 \\
\hline Raw material procurement & 3.206 \\
\hline Operations management & 3.427 \\
\hline Project management & 3.217 \\
\hline Marketing \& distribution network & 3.430 \\
\hline Cost structure & 3.340 \\
\hline
\end{tabular}

To evaluate the strength of the relationship between the critical success factors and productivity of the state, correlation analysis was used. Based on the result in Table 3, all the seven critical success factors have positive and significant relationships with the productivity of the state. The highest value of correlation coefficient is 0.304 which indicates a moderate positive relationship between market positioning and productivity [19]. This is followed by business diversification with the coefficient correlation values 0.301 . The range of correlation coefficient values for another five factors lies between 0.199 to 0.289 which indicate weak positive relationships between the five factors and productivity [19].

Table 3. Correlation Coefficient

\begin{tabular}{|c|c|}
\hline Critical Success Factor & Productivity \\
\hline Market positioning & $.304^{* *}$ \\
\hline Business diversification & $.301^{* *}$ \\
\hline Raw material procurement & $.199^{* *}$ \\
\hline Operations management & $.289^{* *}$ \\
\hline Project management & $.275^{* *}$ \\
\hline Marketing \& distribution network & $.268^{* *}$ \\
\hline Cost structure & $.268^{* *}$ \\
\hline
\end{tabular}

\section{CONCLUSION}

The critical success factor of the business operation for the industrial player in service sectors are varied depends on the type of businesses and the locations where they operate. Majority of the industrial players involve in this study highlight market position, business diversification, operation management and marketing and distribution network as the critical factor of their business operation. It also found that the seven critical success factors examined in this study have positive influence on the productivity of the state. Therefore, to create more competitive enterprises in the services sector, related government agencies such as Pahang Development Skill and others need to increase the number of proper training that will help entrepreneurs improve their skills in managing their business especially in relation to the identified critical factors. Through the empowerment of potential entrepreneurs in the services sector, the government will indirectly boost productivity growth in the state of Pahang.

This study focuses on industrial player in service sector and the geographical scope selected is the eleven districts of Pahang. The result cannot be generalized with other locations and other sectors in Malaysia.

\section{ACKNOWLEDGMENTS}

We gratefully would like to acknowledge funding received from Bahagian Perancang Ekonomi Negeri (BPEN) Pahang. Cordial gratitude is also accorded to all participants who provided valuable insights, excellent support, and feedback.

\section{REFERENCES}

[1] Ministry of International Trade and Industry (MITI) Malaysia, Third Industrial Master Plan (IMP3) 2006-2020, 2006.

[2] W. Yu, and R.. Ramanathan, "Environmental management practices and environmental performance: the roles of operations and marketing capabilities", Industrial Management \& Data Systems, Vol. 116 No. 6, pp. 1201-1222, 2016.

[3] J. B. Barney, "Firm resources and sustained competitive advantage', Journal of Management, vol.17 no.1, pp. 99-121, 1991.

[4] D. J. Teece, G.Pisano, and A. Shuen, "Dynamic capabilities and strategic management", Strategic Management Journal, Vol.18 No.7, pp. 509-534, 1997.

[5] M. Karadeniz, Product Positioning Strategy in Marketing Management. Journal of Naval Science and Engineering, Vol.5 No. 2, pp. 98-110, 2009.

[6] J. Devlin, , C. Ennew, and M. Mirza, “Organisational positioning in retail financial service". Journal of Marketing, Vol. 11 No. 1-3, pp. 119-132, 1995.

[7] M. E. Porter, "What is strategy?", Harvard Business Review, November-December, pp. 61-78, 1996.

[8] S.P. Kalafatis., M.H. Tsogas and C. Blankson., Positioning strategies in business markets in Journal of Business \& Industrial Marketing, vol. 15 issue 6, pp. 416-437, 2000.

[9] L. Han, Literature Review on Diversification Strategy, Enterprise Core Competence and Enterprise Performance, American Journal of 
Industrial and Business Management, vol.9, pp 91108, 2019.

[10]A. Osman and N. Al-Hinal, Project Management versus Operation Management: A comparative study, International Conference on Industrial Engineering and Operation Management, Bandung, Indonesia, March 6-8, 2018.

[11] O. E. Mary, U. K. Enyinna and N.C. Franca. 'Evaluation of Operation Management and its Impact on Improve Logistics Control', International Journal of Economics, Commerce and Management, vol. 3, Iss. 5, 2015.

[12]R.B. Chase, F,R Jacobs, N.J. Aquilano Operations Management nella produzione e nei servizi Milano: McGraw-Hill., 2008.

[13] L.W. Stern, A. I. El-Ansary, and A.T. Coughlan.. Marketing Channels. (5th ed.). Saddle River, NJ: Prentice Hall. 1996.

[14]R. H. Ballou, Unresolved issues in supply chain network design. Information Systems Frontiers, vol. 3, no. 4, pp. 417-426, 2001.

[15]M. Abrahamsson, Time-based distribution. The international journal of logistics, 1993.

[16]P. Baker, An exploratory framework of the role of inventory and warehousing, 2007.

[17] S. R G. Mangiaracina and A. Perego, Distribution network design: a literature review and a research agenda. International Journal of Physical Distribution \& Logistics Management, Vol. 45 No.5, pp.506-531, 2015.

[18]F.N Kerlinger, Foundations of behavioral research New York: Holt,Rinehart \& Winston, 1986.

[19]B. Ratner, A clooser Look The correlation coefficient:Its values range between $+1 /-1$, or do they? Journal of Targeting, Measurement and Analysis for marketing. Vol.17, pp.139-142, 2009. 